\title{
PERMASALAHAN-PERMASALAHAN TERKAIT DENGAN PROFESI GURU SD
}

\author{
Slameto \\ slameto_usw@yahoo.com \\ PGSD \& PPS MP - FKIP - UKSW Salatiga
}

\begin{abstract}
ABSTRAK
Profesionalisme guru sering dikaitkan dengan tiga faktor yang cukup penting, yaitu kompetensi, sertifikasi, dan tunjangan profesi. Ketiga faktor tersebut diprediksi mempengaruhi kualitas pendidikan. Mengingat hasil-hasil penelitian belum mendukung kerangka berpikir seperti itu, maka lahirlah 3 isu terkait dengan sertifikasi guru yaitu: peningkatan hasil belajar siswa yang diajar oleh guru pasca sertifikasi, rendahnya kualitas proises pembelajaran yang diampu oleh guru pasca sertifikasi dan perilaku guru yang kurang profesional. Oleh karena itu perlu pembinaan guru pasca sertifikasi yang harus dilaksanakan secara berkelanjutan, dikarenakan prinsip mendasar bahwa guru harus merupakan manusia pembelajar ( $a$ learning person). Sebagai guru profesional dan telah menyandang sertifikat pendidik, guru berkewajiban untuk terus mempertahankan profesionalismenya sebagai guru. Pengembangan kompetensi dan profesionalisme guru dapat dilakukan melalui upaya pembinaan dan pemberdayaan guru. Dengan demikian perlu upaya peninjauan lebih mendalam terhadap program sertifikasi guru dalam jabatan, khususnya tujuan dan makna sertifikasi, perlu ada upaya pembenahan mind set guru dan perlu ada program perawatan dan pengembangan profesionalisme bagi guruguru yang telah lulus program sertifikasi, khususnya dalam upaya peningkatan mutu layanan pembelajaran. Pengembangan profesionalisme guru pasca sertifikasi perlu kompetensi manajemen, strategi pemberdayaan, supervisi pengembangan, dan penelitian tindakan kelas.
\end{abstract}

Kata kunci: permasalahan kompetensi, sertifikasi, dan profesi guru

\section{PENDAHULUAN}

Sebagaimana dinyatakan dalam UU SPN Nomor 20/2003, UURI No. 14/2005 tentang Guru dan Dosen, dan Peraturan Pemerintah RI No. 19/2005 tentang Standar Nasional Pendidikan, guru dinyatakan sebagai tenaga profesional. Dalam kerangka itulah program sertifikasi guru dilakukan supaya guru memiliki penguasaan kompetensi seba- gaimana dipersyarat-kan UU Guru dan Dosen.

Menurut Keputusan Menteri Pendidikan Nasional No. 045/U/2002, kompetensi diartikan sebagai seperangkat tindakan cerdas dan penuh tanggung jawab yang dimiliki seseorang sebagai syarat untuk dianggap mampu oleh masyarakat dalam melaksanakan tugas-tugas sesuai dengan pekerjaan 
tertentu. Guru sebagai salah satu bagian dari pendidik profesional memiliki tugas utama mendidik, mengajar, membimbing, mengarahkan, melatih, menilai, dan mengevaluasi peserta didik pada pendidikan anak usia dini jalur pendidikan formal, pendidikan dasar, dan pendidikan menengah. Dalam melaksanakan tugasnya, guru menerapkan keahlian, kemahiran yang memenuhi standar mutu atau norma tertentu yang diperolehnya melalui pendidikan profesi.

Pengakuan kedudukan guru sebagai tenaga profesional dibuktikan dengan sertifikat pendidik dan diberikan kepada guru yang telah memenuhi syarat. Selanjutnya, bagi guru yang telah memiliki sertifikat pendidik berhak memperoleh penghasilan di atas kebutuhan hidup minimum dan jaminan kesejahteraan sosial. Penghasilan di atas kebutuhan hidup minimum meliputi gaji pokok, tunjangan yang melekat gaji, serta penghasilan lain berupa tunjangan profesi, tunjangan fungsional, tunjangan khusus, dan maslahat tambahan yang terkait dengan tugasnya sebagai guru yang ditetapkan dengan prinsip penghargaan atas dasar prestasi.

Guru yang layak menerima tunjangan sebagai upaya perbaikan nasibnya agar profesi yang dijalaninya selama ini "diakui" sebagai profesi dan "disamakan" dengan profesi-profesi lainnya yang dianggap layak sebagai profesi. Guru benar-benar sebagai sosok yang siap untuk digugu dan ditiru, siap memenuhi panggilan tugas dan kewajiban dengan segala tanggung jawabnya, kemudian siap menerima tunjangan sebagai konsekuensi dari sebuah profesionalitas.

Guru memiliki peran strategis dalam bidang pendidikan; guru merupakan ujung tombak dalam upaya peningkatan kualitas layanan dan hasil pendidikan. Sayangnya kualitas guru di Indonesia masih tergolong relatif rendah. Berdasarkan survey UNESCO, terhadap kualitas para guru, kulitas guru kita berada pada level 14 dari 14 negara berkembang. Hal ini antara lain disebabkan oleh tidak terpenuhinya kualifikasi pendidikan minimal. Data dari Balitbang Depdiknas pada tahun 2005 menunjukkan terdapat 1.646 .05 $(69,45 \%)$ guru SD, SMP, SMA, SMK, dan SLB yang tidak memenuhi kualifikasi pendidikan minimal (Tim Sertifikasi Guru, 2006).

Permasalahan yang muncul kemudian adalah tingkat profesionalisme guru pasca sertifikasi. Setelah ada jaminan kesejahteraan yang lebih baik dari sebelumnya, apakah mereka yang telah disertifikasi itu lebih baik dari sebelumnya? Atau bagaimana perbandingannya dengan guru yang belum disertifikasi? Pertanyaan ini untuk menggugah, terutama tanggungjawab moral dalam membina generasi ke depan.

Banyak kalangan masyarakat yang memandang pesimis dengan pelaksanaan program sertifikasi guru. 
Selain ketidakjelasan dalam proses pelaksanaannya, kompetensi guru pasca sertifikasi masih dianggap kurang menunjang kinerja guru dalam mengajar sehingga kualitas pendidikan Indonesia di dunia masih jauh tertinggal (Miftha Indasari, 2013). Retno Listyarti, Sekretaris Jenderal Federasi Serikat Guru Indonesia, mengatakan, tujuan sertifikasi untuk meningkatkan mutu guru tidak berjalan baik. Sebab, pemerintah tidak punya konsep yang jelas soal pembinaan guru. "Setelah uang sertifikasi diberikan, pemerintah lepas tangan," (kompas, 2012) .

\section{PEMBAHASAN}

Fasilitasi sesi ini berupaya mengidentifikasi Isyu-isyu strategis terkait dengan Permenagpan - RB no 16 tahun 2009; sedemikian hingga merupakan upaya sosialisasi dan penyadaran bagi para guru SD pasca sertifikasi tentang pentingnya peraturan dan perundang-undangan yang menjadi landasan pengembangan profesionalitasnya. Selain itu, yang tidak kalah pentingnya adalah sebagai upaya pencegahan agar para guru pasca sertifikasi dalam bekerja sebagi guru profesional menjadi produktif, tidak terjebak dalam ketidak-layakan mana kala dilakukan penilaian kinerja. Disamping memaparkan uraian tentang permasalahan seputar sertifikasi dan profesionalitas guru pasca sertifikasi berdasarkan hasil-hasil penelitian dan kaitannya dengan layanan pembelajaran, fasilitator ini juga mengundang partisipasi peserta untuk memunculkan ide-ide cemerlang dalam mencari solusi untuk meningkatkan kualitas pendidikan/ pembelajaran sebagai dampak sertifikasi guru.

\section{Sajian Hasil Penelitian}

Temuan D. Deni Koswara, Asep Suryana, dan Cepi Triatna dengan judul Studi Dampak Program Sertifikasi Guru Terhadap Peningkatan Profesionalisme dan Mutu Di Jawa Barat tahun 2009 diperoleh ringkasan hasil seperti berikut ini.

\begin{tabular}{|c|c|}
\hline Temuan yang menggembirakan & Temuan yang memprihatinkan \\
\hline $\begin{array}{l}\text { Data umum mengenai profesionalisme guru } \\
\text { SMP pada sekolah-sekolah yang diteliti } \\
\text { menunjukkan kategori baik dengan } \\
\text { capaian skor instrumen penelitian sebesar } \\
\mathbf{3 , 2 2} \text {. Hal ini berarti bahwa dilihat dari rasa } \\
\text { pengabdian, pemahaman terhadap kewajiban } \\
\text { sosial, kemandirian, dan keyakinan terhadap } \\
\text { profesi guru-guru yang menjadi responden } \\
\text { penelitian dikategorikan baik. }\end{array}$ & $\begin{array}{l}\text { Sertifikasi pada guru SMP yang diteliti di } \\
\text { Jawa Barat berkorelasi sangat rendah } \\
\text { terhadap peningkatan profesionalisme dan } \\
\text { mutu pembelajaran. } \\
\text { 1. Sertifikasi guru tidak berkontribusi } \\
\text { terhadap profesionalisme guru. } \\
\text { 2. Sertifikasi guru tidak berkontribusi } \\
\text { terhadap mutu pembelajaran. }\end{array}$ \\
\hline
\end{tabular}


Guru adalah tenaga profesional. Program sertifikasi guru dilakukan supaya guru memiliki penguasaan kompetensi sebagaimana dipersyaratkan UU Guru dan Dosen. Salah satu tujuan sertifikasi guru adalah untuk meningkatkan proses dan mutu hasil pendidikan. Guru yang memperoleh tunjangan profesi dikategorikan sebagai guru profesional. Temuan D. Deni Koswara, dkk. tahun 2009 ternyata sertifikasi guru SMP di Jawa Barat berkorelasi sangat rendah terhadap peningkatan profesionalisme dan mutu pembelajaran; Sertifikasi guru tidak berkontribusi terhadap profesionalisme guru; tidak berkontri-busi terhadap mutu pembelajaran.

Selanjutnya hasil kajian Bank Dunia mengkonfirmasi kegagalan program sertifikasi guru di Indonesia. Tidak adanya hubungan yang jelas antara program sertifikasi dengan peningkatan mutu pembelajaran. Tak tanggung-tanggung Bank Dunia meneliti pelaksanaan setifikasi guru untuk kurun waktu 2009, 2011, dan 2012. Sasaran penelitian adalah 240 Sekolah Dasar, 120 Sekolah Menengah Per- tama, 3000 guru, dan 90.000 siswa. Temuan pertama, sertifikasi tidak mengubah praktik mengajar dan perilaku guru. Kedua, peningkatan pendapatan guru yang lolos sertifikasi ekuivalen dengan peningkatan mutu mengajar (Kompas, 2012). Temuan dari kajian itu dipaparkan oleh Head of Human Development Sector Indonesia Bank Dunia, Mae Chu Chang pada pertemuan Organisasi Guru ASEAN di Denpasar, Bali menyebutkan bahwa belum jelasnya manfaat sertifikasi. Bahkan sejumlah penelitian membuktikan bahwa peningkatan profesionalisme pendidik tidak berpengaruh positif terhadap peningkatan mutu pendidikan, sehingga akan terlalu cepat untuk mengatakan bahwa relevansi kebijakan sertifikasi pendidik dengan peningkatan kesejahteraan pendidikan dan mutu pendidikan.

Penelitian Badrun dengan judul "Kinerja Guru Profesional (Guru Pasca Sertifikasi)di Kabupaten Sleman" tahun 2011 diperoleh hasil dalam ringkasan seperti berikut ini. 


\begin{tabular}{|c|c|}
\hline Temuan yang menggembirakan & Temuan yang memprihatinkan \\
\hline $\begin{array}{l}\text { Kemampuan guru profesional (guru } \\
\text { pasca sertifikasi) dalam menyusun RPP } \\
\text { dan melaksanakan pembelajaran sudah } \\
\text { baik. Berdasarkan penilaian kepala } \\
\text { sekolah, kompetensi kepribadian dan } \\
\text { sosial para guru yang sudah lulus } \\
\text { sertifikasi dan telah menerima tujangan } \\
\text { profesi sangat baik. } \\
\text { Upaya sebagian besar guru dalam } \\
\text { membimbing siswa mengikuti lomba } \\
\text { atau olimpiade sudah baik. }\end{array}$ & $\begin{array}{l}\text { Kinerja sebagian besar guru profesional } \\
\text { (pasca sertifikasi) yang ada di } \\
\text { Kabupaten Sleman belum baik; dari } 17 \\
\text { indikator yang diteliti, } 7 \text { indikator baik } \\
\text { dan } 10 \text { indikator lainnya belum baik. } \\
\text { Upaya atau aktivitas sebagian besar guru } \\
\text { yang telah lulus sertifikasi dan telah } \\
\text { menerima tunjangan profesi masih } \\
\text { belum menggembirakan, terutama } \\
\text { yang terkait dengan: } \\
\text { (1) penulisan artikel; } \\
\text { (2) penelitian; } \\
\text { (3) membuat karya seni/teknologi; } \\
\text { (4) menulis soal UN; } \\
\text { (5) menelaah buku; } \\
\text { (6) mengikuti kursus Bahasa Inggris, } \\
\text { (7) mengikuti diklat, dan } \\
\text { (8) mengikuti forum ilmiah }\end{array}$ \\
\hline $\begin{array}{l}\text { Usaha sebagian besar guru yang telah } \\
\text { lulus sertifikasi dan telah menerima } \\
\text { tunjangan profesi dalam: } \\
\text { (1) membuat modul; dan } \\
\text { (2) membuat media pembelajaran baik. }\end{array}$ & $\begin{array}{l}\text { Aktivitas di organisasi pendidikan dan } \\
\text { sosial belum baik, } \\
\text { (1) ada sebagian }(47,5 \%) \text { guru yang } \\
\text { telah lulus sertifikasi dan telah } \\
\text { menerima tunjangan profesi menjadi } \\
\text { pengurus organisasi sosial; } \\
\text { (2) } 30 \% \text { guru menjadi pengurus } \\
\text { organisasi pendidikan }\end{array}$ \\
\hline
\end{tabular}

Penelitian Badrun di Kabupaten Sleman tahun 2011 menyatakan kinerja sebagian besar guru profesional (pasca sertifikasi) belum baik, upaya sebagian besar guru yang telah lulus sertifikasi masih belum menggembirakan. Itu semua merupakan persoalan serius yang memerlukan solusi cerdas.

Asumsi bahwa sertifikasi akan meningkatkan profesionalisme guru dan mutu pendidikan, ternyata kondisi dilapangan berbeda; apa yang dialami guru dalam sertifikasi belum memberikan dampak secara signifikan pada kemampuan professional guru termasuk terhadap peningkatan mutu pembelajaran. Bahkan muncul beberapa kasus yang tidak diharapkan, dimana ada guru yang menjadi lebih tidak disiplin pasca sertifikasi, ada pula yang meng- 
asumsikan bahwa sertifikasi adalah suatu kondisi final dari profesi keguruan. Apabila diperbandingkan dengan sebelum sertifikasi, banyak guru yang sering mengikuti pengembangan kemampuan melalui berbagai pelatihan, workshop dan seminar, namun setelah sertifikasi dan dinyatakan lulus mereka cenderung tidak mengikuti lagi kegiatankegiatan tersebut. Lebih jauh, alokasi dana tunjangan profesi yang diterima guru-guru sedikit sekali proporsinya yang digunakan untuk pengembangan profesi, bahkan kecenderungannya tidak digunakan untuk pengembangan profesi guru lebih lanjut. Para guru lebih banyak mengalokasikan dana tunjangan profesinya untuk pemenuhan sandang, pangan dan papan, seperti pembelian tanah, rehab rumah, pembelian kendaraan bermotor, ditabung di bank, dan sebagainya.

\section{Isyu-isyu strategis terkait}

\section{Implementasi Permenagpan-RB nomor 16 tahun 2009}

Mengimplementasikan berarti melengkapi atau menyediakan sarana untuk melaksanakan sesuatu yang mencakup 4 komponen: a). Menciptakan dan menyusun staf sebuah agen baru untuk melaksana-kan sebuah kebijakan baru, b). Menterjemahkan tujuan legislatif dan serius memasukkannya ke dalam aturan pelaksanaan, mengembangkan panduan atau kerangka kerja bagi para pelaksana kebijakan, c). Melakukan koordinasi terhadap sumberdaya agen dan pembiayaan bagi kelompok sasaran, mengembangkan pembagian tanggungjawab para agen dan antar para agen serta hubungan antar agen, dan d). Mengalokasikan sumberdaya untuk memperoleh dampak kebijakan. (Arif Rohman, 2009).

Seperti dipaparkan di atas, bahwa sertifikasi guru yang semestinya meningkatkan kesejahteraan dan kualitas guru agar terjadi peningkatan kualitas pendidikan di kelas dan sekolah ternyata tak berjalan seperti yang diharapkan. Prestasi siswa tak meningkat signifikan, sertifikasi tak mengubah praktik mengajar dan tingkah laku guru. Perubahan yang dilakukan pemerintah untuk membayar lebih guru tak diterjemahkan oleh guru dalam hasil belajar yang bagus. Dengan demikian terdapat beberapa isyu strategis didalam implementasi kebijakan sertifikasi ini. Pertama terkait dengan peningkatan hasil belajar siswa yang diajar oleh guru pasca sertifikasi. Kedua terkait dengan rendahnya kualitas proises pembelajaran yang diampu oleh guru pasca sertifikasi. Ketiga terkait dengan perilaku guru yang kurang profesional.

Peningkatan hasil belajar siswa (yang diajar oleh guru pasca sertifikasi) memang secara empiris dipengaruhi oleh banyak faktor, namun pengaruh faktor (kompetensi) guru bisa mencapai sebesar 25,5\% (Jayengsari, R. 2013). Bahkan hasil penelitian Wuri Sylvia 
Sarce (2010) untuk mata pelajaran IPS Terpadu SMP, menemukan bahwa besarnya sumbangan kompetensi pedagogik guru terhadap hasil belajar siswa sebesar 94,50\%.

Terkait dengan isyu rendahnya kualitas proses pembelajaran yang diampu oleh guru pasca sertifikasi dapatlah dijelaskan seperti temuan Bank Dunia yang menyatakan bahwa sertifikasi tidak mengubah praktik mengajar dan perilaku guru; peningkatan pendapatan guru yang lolos sertifikasi tidak ekuivalen dengan peningkatan mutu mengajar (Kompas, 2012). Selanjutnya hasil kajian Bank Dunia mengkonfirmasi tidak adanya hubungan yang jelas antara program sertifikasi dengan peningkatan mutu pembelajaran; Sertifikasi guru tidak berkontribusi terhadap profesionalisme guru; tidak berkontribusi terhadap mutu pembe-lajaran. Mengapa demikian? Salah satu dugaan kuatnya karena terkait dengan isyu yang ketiga yaitu peri-laku guru yang kurang profesional.

Terkait dengan isyu yang ketiga yaitu perilaku guru yang kurang profesional seperti dipaparkan oleh Badrun (2011) guru yang telah lulus sertifikasi dan telah menerima tunjangan sertifikasi justru lebih tidak disiplin, banyak guru yang tidak mau mengikuti pengembangan kemam-puan melalui berbagai pelatihan, workshop dan seminar; alokasi dana tunjangan profesi yang diterima guru-guru sedikit sekali proporsinya yang digunakan untuk pengembangan profesi, bahkan kecenderungannya tidak digunakan untuk pengembangan profesi guru lebih lanjut. Terkait dengan kegiatan profesional, jarang sekali guru pasca sertifikasi yang melakukan kegiatan: penulisan artikel, Penelitian, membuat karya seni/teknologi, menulis soal UN, menelaah buku, mengikuti kursus Bahasa Inggris, mengikuti diklat, dan mengikuti forum ilmiah.

Ketiga isyu tersebut dipengaruhi oleh faktor 1) standar dan tujuan kebijakan; 2) sumberdaya; 3) komunikasi; 4) interorganisasi dan aktivitas pengukuhan; 5) karakteristik agen pelaksana; 6) kondisi sosial, ekonomi, dan politik, serta karakter pelaksana. Agar isyu-isyu tersebut segera teratasi, para pelaku kebijakan harus memiliki kemempuan manaje-rial, dan politis serta komitmen terhadap tujuan yang akan dicapai. Para pemimpin dapat mengambil langkah bukan hanya pada ranah merencanakan sebuah peraturan namun dalam pengangkatan personil baru non layanan masyarakat, guna meningkatkan isi dan keterdukungan pemimpin terhadap pancapaian tujuan sertifikasi.

\section{Upaya Profesional Guru pasca Sertifikasi}

Asumsi bahwa sertifikasi akan meningkatkan profesionalisme guru dan mutu pendidikan, ternyata kondisi dilapangan berbeda; apa yang dialami guru dalam sertifikasi belum memberikan dampak secara signifikan pada 
kemampuan professional guru termasuk terhadap peningkatan mutu pembelajaran. Bahkan muncul beberapa kasus yang tidak diharapkan. Untuk menjamin konsistensi profesionalisme guru seiring dengan perkembangan ilmu pengetahuan, teknologi, dan seni, diperlukan upaya-upaya peningkatan profesionalisme secara berkesinambungan. Secara preskriptif dukungan kompetensi manajemen, strategi pemberdayaan, supervisi pengembangan, dan penelitian tindakan kelas merupakan dimensi-dimensi alternatif untuk meningkatkan profesionalisme guru.

Dukungan kampetensi manajemen diperankan oleh dinas pendidikan dan kepala sekolah; Kompetensi manajemen yang dibutuhkan unruk peningkatan profesionaiisme guru dibedakan atas tiga aras, yaitu (1) manajemen aras kebijakan di tingkat birokrasi dinas pendidikan, (2) manajemen aras sekolah di tingkat kepala sekolah, dan (3) manajemen aras operasional di tingkat guru (Surya Dharma, 2003). Pada aras kebijakan di tingkat dinas pendidikan, menurut Santyarsa (2008) dibutuhkan kompetensi tentang (1) pemikiran strategik (strategic thinking), (2) kepemimpinan yang berubah (change leadership), dan (3) manajemen hubungan (relationship management). Pada aras sekolah oleh kepala sekolah, dibutuhkan kompetensi-kompetensi; (1) fleksibilitas, (2) terapan perubahan, (3) pemahaman interpersonal, (4) pemberdayaan, (5) fasilitasi tim, dan (6) portabilitas (Santyarsa, 2008). Pada aras operasional di tingkat personal guru, dibutuhkan kompetensi; (1) fleksibilitas, (2) mencari dan menggunakan informasi, motivasi, dan kemampuan untuk belajar, (3) motivasi berprestasi, (4) motivasi kerja di bawah tekanan waktu, (5) kolaboratif, dan (6) orientasi pelayanan kepada siswa (Santyarsa, 2008).

Pembinaan serta pemberdayaan kompetensi guru pasca sertifikasi akan ikut pula menentukan peningkatan mutu pendidikan. Dengan adanya KKG dan MGMP maka guru yang sudah dibekali dengan pendidikan kompetensi akan bisa saling berbagi pendapat dan meningkatkan kinerjanya sebagai guru yang professional. KKG dan MGMP merupakan wadah bagi guru untuk melakukan kegiatan yang bermanfaat bagi tugas keprofesionalannya. Selain itu, guru juga perlu diberdayakan kemampuannya dalam mengimplementasikan kompetensi yang telah mereka miliki serta harus terus diberikan motivasi oleh pihak manajemen sekolah. Dengan demikian, meningkatanya penguasaan kompetensi guru maka akan meningkatkan kinerja guru yang akan berdampak pula pada meningkatnya kualitas pendidikan. Maka, perlu adanya peran utama dari pemerintah dalam memberdayakan kembali kemampuan guru-guru pasca sertifikasi. Dalam dunia pendidikan, 
pemberdayaan merupakan cara yang sangat praktis dan produktif untuk mendapatkan hasil yang terbaik dari kepala sekolah, para guru, dan para pegawai. Dalam standar kompetensi dan sertifikasi guru, pemberdayaan dimaksudkan untuk memperbaiki kinerja sekolah, melalui kinerja guru agar dapat mencapai tujuan secara optimal, efektif, dan efisien. Pemberdayaan guru melalui standar kompetensi dan sertifikasi guru terjadi melalui beberapa tahapan (Hanafiah, 2010: 161). Pertama, guru-guru mengembangkan sebuah kesadaran awal bahwa mereka bisa melakukan tindakan untuk meningkatkan kehidupannya dan memperoleh seperangkat keterampilan agar mampu bekerja dengan baik. Tahap kedua, mengurangi rasa ketidakmampuannya dan mengalami peningkatan kepercayaan diri. Tahap ketiga, seiring dengan tumbuhnya keterampilan dan kepercayaan diri, para guru bekerja sama untuk berlatih lebih banyak mengambil keputusan dan memilih sumber-sumber daya yang akan berdampak pada kesejahteraan.

Strategi pemberdayaan dan supervisi pengembangan merupakan peran sentral kepala sekolah; Strategi pemberdayaan adalah salah satu cara pengembangan guru melalui employee involvement. Analog dengan pikiran Wahibur Rokhman (2003), dapat dikonsepsikan bahwa pemberdayaan merupakan upaya kepala sekolah untuk meberikan wewenang dan tanggung jawab yang proporasional, menciptakan kondisi saling percaya, dan pelibatan guru dalam menyelesaikan tugas dan pengambilan keputusan. Kepala sekolah memiliki peran strategis dalam proses pemberdayaan guru sebagai agen perubahan. Dalam hal ini kepala sekolah dituntut memiliki kesadaran yang tinggi dalam mendistribusi wewenang dan tanggung jawab secara proporsional. Cara ini di satu sisi dapat merupakan proses kaderisasi, dan di sisi lain sekaligus sebagai proses peningkatan kompetensi guru secara berkelanjutan.

Pendekatan supervisi pengembangan (developmental supervision) bertolak dari kenyataan, bahwa pada dasarnya proses supervisi adalah proses belajar. Dalam proses supervisi, hubungan antara kepala sekolah analog dengan hubungan antara guru dengan siswa. Guru dalam melayani siswa memiliki kewajiban untuk memahami semua karakteristik siswa. Demikian pula, kepala sekolah dalam melakukan supervisi kepada guru, seyogyanya guru diperhatikan sebagai individu, karena ada perbedaan-perbedaan individual dalam perkembangan manusiawinya. Perlakuan ini sangat diperlukan, terlebih jika guru dituntut untuk terlibat secara langsung dalam peningkatan kualitas pendidikan. Pendekatan supervisi perlu didasarkan atas perkembangan, kebutuhan, dan karakteristik guru. Pendekatan ini erat kaitannya dengan dua unsur penting keefektifan 
guru dalam menjalankan tugas keprofesionalan, yaitu komitmen dan kemampuan berpikir abstraks. Komitmen guru merupakan banyaknya waktu dan tenaga yang mampu dicurahkan oleh guru tersebut bagi siswa dan mengembangkan profesinya. Komitmen diistilahkan sebagai kepedulian, yang dapat diklasifikasi atas tiga kategori, yaitu kepedulian terhadap diri sendiri, terhadap siswa, dan terhadap profesionalisme. Kemampuan berpikir abstraks, adalah kemampuan kognitif berbasis pengalaman konkrit, mampu mengidentifikasi tindakan kekinian untuk membantu siswa belajar secara efektif, dan mampu mengidentifikasi tindakan yang akan datang yang lebih memberikan kesuksesan pelayanan bagi siswa.

Guru profesional secara teoretis akan mampu meningkatkan kualitas pembelajaran di kelas, memberikan layanan pembelajaran kepada siswa untuk belajar secara interaktif, inspiratif, memotivasi, menantang, dan menyenangkan. Pembelajaran seperti itu akan dapat diwujudkan oleh guru, apabila guru secara kontiniu melakukan penelitian tindakan kelas atau PTK. PTK adalah suatu bentuk penelitian yang bersifat reflektif mandiri, yang dapat digunakan dalam proses pengembangan kurikulum sekolah, perbaikan sekolah, dan perbaikan kualitas pembelajaran di kelas. PTK sangat bermanfaat dalam membangun hubungan interpersonal, tipe pembelajaran yang bervariasi, pengukuran bentuk-bentuk wacana kelas, penyelidikan terhadap manusia dengan melakukan komunikasi interpersonal selektif dan langsung. Kesahihan PTK bersifat personal, dan tidak semata-mata menekankan kesahihan metodologis. Para guru diseyogyakan untuk melakukan PTK seeara berkesinambungan. Praktik pembelajaran yang dikritisi dengan kemudian ditindaklanjuti dengan upaya perbaikan melalui PTK, secara bertahap akan meningkatkan profesionalisme guru.

\section{PENUTUP}

Dalam upaya meningkatan mutu pendidikan, guru merupakan salah satu faktor yang amat penting; oleh karena itu guru dinyatakan sebagai tenaga professional. Dalam kerangka itulah program sertifikasi guru dilakukan supaya guru memiliki penguasaan kompetensi sebagaimana dipersyaratkan UU Guru dan Dosen. Profesionalisme guru sering dikaitkan dengan tiga faktor yang cukup penting, yaitu kompetensi, sertifikasi, dan tunjangan profesi. Ketiga faktor tersebut diprediksi mempengaruhi kualitas pendidikan. Mengingat hasil-hasil penelitian belum mendukung kerangka berpikir seperti itu, maka lahirlah 3 isu terkait dengan sertifikasi guru yaitu: peningkatan hasil belajar siswa yang diajar oleh guru pasca sertifikasi, rendahnya kualitas proises pembelajaran yang diampu oleh guru pasca sertifikasi dan perilaku guru yang 
kurang profesional. Oleh karena itu perlu pembinaan guru pasca sertifikasi yang harus dilaksanakan secara berkelanjutan, dikarenakan prinsip mendasar bahwa guru harus merupakan manusia pembelajar (a learning person).

Sebagai guru profesional dan telah menyandang sertifikat pendidik, guru berkewajiban untuk terus mempertahankan profesionalismenya sebagai guru.

Pengembangan kompetensi dan profesionalisme guru dapat dilakukan melalui upaya pembinaan dan pemberdayaan guru.
Dengan demikian perlu upaya peninjauan lebih mendalam terhadap program sertifikasi guru dalam jabatan, khususnya tujuan dan makna sertifikasi, perlu ada upaya pembenahan mind set guru dan perlu ada program perawatan dan pengem-bangan profesionalisme bagi guru-guru yang telah lulus program sertifikasi, khususnya dalam upaya-upaya peningkatan mutu layanan pembelajaran. Pengembangan profesionalisme guru pasca sertifikasi perlu kompetensi manajemen, strategi pemberdayaan, supervisi pengembangan, penelitian tindakan kelas.

\section{DAFTAR PUSTAKA}

Badrun Kartowagiran. 2011. Kinerja Guru Profesional (Guru yang Sudah Lulus Sertifikasi Guru dan Sudah Mendapat Tunjangan Profesi) di Kabupaten Sleman Yogyakarta. Pusat Kajian Pengembangan Sistem Pengujian dan Pusat Kajian Pendidikan Dasar dan Menengah, Lembaga Penelitian Universitas Negeri Yogyakarta

Deni Koswara, Asep Suryana, Cepi Triatna, 2009. Studi Dampak Program Sertifikasi Guru Terhadap Peningkatan Rofesionalisme dan Mutu di Jawa Barat. file.upi.edu/Direktori/ FIP/JUR._ ADMINISTRASI_PENDIDIKAN/...

Haryono, 2010. Manajemen Peningkatan Profesionalisme Guru Pasca Sertifikasi, Makalah Disajikan dalam Program Teaching Clinic Pascasertifikasi Guru yang Diselenggrakan oleh Bidang PPTK Dinas Pendidikan Propvinsi Jawa Tengah Tahun 2010, dapat diakses pada http://budisusetyo.typepad.com /blog/2012/01/manajemen-peningkatan-profesionalisme-gurupascasertifikasi.html 
Jayengsari, Reksa. 2013. Pengaruh Kompetensi Guru Terhadap Prestasi Belajar Siswa Pada Mata Pelajaran Akuntansi Di SMK Se-Kota Bandung. S1 Thesis, Universitas Pendidikan Indonesia.

Kompas, 2012. Sertifikasi Guru Disorot. http://tekno.kompas.com/read/2012/08/06/ 11001445/Sertifikasi.Guru.Disorot

Ratna Ayu, 2010. Membangun Kompetensi dan Profesionalisme Guru: Suatu Refleksi Pelaksanaan Sertifikasi Guru Dalam Meningkatkan Kualitas Pendidikan. http://ratna-ayu.blogspot.com/ 2010/01/ membangunkompetensi-dan.html

Republik Indonesia. 2005. Undang- UndangRepublik Indonesia Nomor 14 Tahun 2005 Tentang Guru dan Dosen. Jakarta.

Santyarsa, I Wayan. 2008. "Dimensi-Dimensi Teoretis Peningkatan Profesionalisme Guru". http://www. koranpendidikan.com/artikel-8095.pdf

Siswanta, Jaka. 2009. Meningkatkan Profesionalitas Pendidik Melalui Program Sertifikasi Pendidikan. Jurnal Mudarrisa, 1 (2).

Slameto, 2008. Peran Kepala Sekolah dalam Optimalisasi Kompetensi Pedagogik Guru. Bintek Teaching Clinik Pasca Sertifikasi Bagi Kepala Sekolah, Dinas Pendidikan Provinsi Jawa Tengah.

Tim. 2006. Naskah akademik. Jakarta: Ditjen Dikti.

Wuri Sylvia Sarce 2010. Pengaruh Kompetensi Pedagogik Guru Terhadap Prestasi Siswa dalam Mata Pelajaran IPS Terpadu di SMP Negeri 01 Suboh-Situbondo. UIN Malang. 